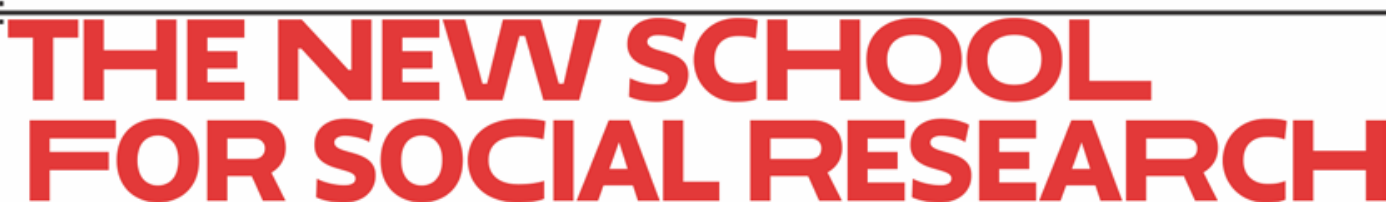

Joshua Greenstein

\title{
The Precariat Class Structure and Income Inequality Among US Workers: 1980-2018
}

June 2019

Working Paper 11/2019

Department of Economics

The New School for Social Research 
The Precariat Class Structure and Income Inequality Among US Workers: 1980-2018

\author{
Joshua Greenstein \\ Assistant Professor of Economics \\ Hobart and William Smith Colleges \\ greenstein@hws.edu
}

I apply the precariat class schema developed by Standing to the US workforce from 1980-2018. I use a decomposition of inequality to show that this schema explains a substantial and growing portion of income inequality. I find that that the precariat, typified by unstable and benefit-free jobs, make up a large and growing share of the US work force, that the "old" working class shrank precipitously, and that the demographics of these two classes differ substantially. Finally, I illustrate that insight into these difficult to measure phenomena can be gained with an easily replicable class schema using plausible class definitions.

JEL CODES: B59 D63 J21 J42 O17

Keywords: Economic Class, Precarious labor, Inequality, Distribution, Structural change

Main text word count: 5490 


\section{Introduction}

It is widely understood that income inequality in the United States has been increasing during the most recent decades (See, for example, Tcherneva 2015, Piketty, Saez, and Zucman 2016). There are many different theories attempting to explain this phenomena, such as changing capital-labor shares (Piketty 2013), changing returns to human capital and skill-biased technological change (Autor, Katz, and Kearney 2006, Kaplan and Rau 2013, Acemoglu and Restreppo 2017, Autor and Salomons 2018), and oligopoly and firm market power due to market concentration (Autor et al 2017, Bloom 2017). Other researchers have focused more on changing institutions and relationships between employers and workers (Stiglitz 2013, Weil 2014, Baker 2015, Tcherneva 2015, Howell and Kalleberg 2019). Still others have focused on the importance of economic class, and potential changes to the economic class structure (Wolff and Zacharias 2013, Standing 2009, 2014, 2015, Temin 2017, Naidu 2017). Changing institutions and changing class structure can be viewed as related, rather than competing, phenomena.

This paper examines the effect of a changing class structure on patterns of distribution in the US. To do so, I rely on the class schema laid out by Standing $(2009,2014,2015)$. The central idea of this class schema is a change in the relationship of workers to their work. In particular, Standing focuses on a transformation from an "old" working class to a "new" working class, the "precariat." The precariat differs from the old working class mainly due to their insecurity; they are a flexible labor source, dependent on money wages due to a loss of labor rights and weakened ability to access the welfare state, and without stable long term employment (Standing 2009, 2014, 2015).

In this paper, I illustrate how the precariat class schema can be applied empirically to data on the US workforce to help understand the changing nature of working class jobs and of who holds those jobs. In addition, I also illustrate the extent to which this class structure can explain growing income inequality in the US. Measuring these changes in types of work is typically thought to be very difficult (Howell and Kalleberg 2019). I show that even very simple definitions using readily available data can be used to create class categories that both plausibly match Standing's definitions, and clearly illustrate changing trends in work and a substantial impact on inequality.

\section{Precarious Labor in the US and the World}

There has been a global shift away from the employment model of wage-earners in stable jobs with a traditional employer-employee relationship, leading to labor becoming more insecure. Such jobs represent only about half of global employment and as little as twenty percent of employment in developing regions 
(ILO 2015). As short term contracts and irregular hours have become more widespread, fewer than half of all wage and salaried workers were considered permanent full time employees globally (ILO 2015). A recent study also found an increase in "gig economy" and "digital labor" jobs in middle income countries. Concerns about these jobs included instability and insecurity, lack of benefits, isolation, physical/mental exertion, and lack of bargaining power (Graham et al 2017). In addition to institutional changes, deindustrialization has altered the types of jobs available globally (UNRISD 2010, McMillan and Rodrik 2012; van der Hoeven 2012, Kunst 2019), potentially leading to effects on distribution and well-being (UNRISD 2010, Greenstein and Anderson 2017, Greenstein 2019). The potentially deleterious effects of these phenomena are illustrated by such trends as a declining employment-population ratio (van der Hoeven 2012), a high share of workers in the informal economy, (van der Hoeven 2012, ILO 2015), and a declining wage share and increased income inequality (van der Hoeven 2012).

Wage and salaried employment has also been on a downward trend in wealthy economies (ILO 2015). Breman and van der Linden (2014) suggest that a trend towards precarization in the wealthy world is inevitable due to a stagnant economy, dismantled welfare state, and decline of unions, among other causes. In the US, there is evidence that the nature of and types of work have been changing in recent decades, though there is debate over the extent of these changes. US jobs in general, and working class jobs in particular, have been declining in quality as measured by pay, benefits, and working conditions (Howell and Kalleberg 2019). Median hourly wages for working class jobs have been falling since the 1980s (Draut 2016), and the general decline in the share of workers with employer-provided health insurance and pensions has been even more severe for low wage workers (Howell and Kalleberg 2019). The types of jobs done by the working class have also changed, as the half-century decline in manufacturing as a percent of total employment for half of a century has accelerated in the last twenty years (Fort et al 2018). Non-college workers are now overwhelmingly employed in the service sector, and the share of non-college workers in industrial jobs such as manufacturing and construction has been declining precipitously in recent decades (Draut 2016, Rowell 2017).

Some researchers hypothesize that increased outsourcing of jobs to small, cost competitive subcontractors, increased self-employment (perhaps related to the "gig economy"), and increased temporary or part-time employment have been driving forces in lowering job quality (Weil 2014, Hill 2015). Draut (2016) notes the increased use of temporary staffing by large industrial sector employers such as the auto industry. These changes are illustrated anecdotally in a recent report that Google's temporary and contract employees now outnumber that company's full-time employees (Wakabayashi 2019). There is some uncertainty over the 
extent of these trends. In 2018, the BLS estimated that 15.5 million workers, about ten percent of the workforce had "alternative arrangements for their primary employment." This category included, for example, independent contractors and temporary help agency workers (BLS 2018). These numbers were in addition to the contingent workers who reported that their jobs were temporary, numbering about 5.9 million workers or 3.8 percent of the workforce (BLS 2018). These findings were both somewhat of a decline from similar estimates in previous years (BLS 2018, Shambaugh, Nunn, and Laurer 2018), leading some to claim that perceptions of changing work arrangements were overblown (Casselman 2018, Maye 2019). In response, Katz and Krueger revised down a previous estimate of a five percentage point increase in alternative work arrangements from 2005 to 2015 (Katz and Krueger 2016), to only a 1-2 percentage point increase over the same period (Katz and Krueger 2019).

However, estimates of these categories are highly dependent on definitions, measurement choices, and data source. The GAO (2015) reported that different reasonable definitions of contingent work could find estimates ranging from less than five percent to more than a third of the labor force (GAO 2015). In another example, tax records suggest more of an increase in independent contracting and self-employment than the BLS survey data (Abraham et al. 2017). Further, the BLS approach would not include jobs of the type emphasized by Weil (2014), that have been subcontracted to smaller firms and may offer lower pay and benefits than similar jobs at larger employers, as part of the "alternative arrangement" (Casselman 2018). Finally, the lack of any data at all on these types of work arrangements until relatively recently makes it very difficult to assess long-term trends (Howell and Kalleberg 2019). At any rate, Howell and Kalleberg (2019) do note that much of the decline in quality associated with temporary or contract jobs, such as the loss of nonmonetary benefits, has been mirrored in jobs with more traditional employment relations.

In addition to these changes in the types of work that the working class in the US does, the demographics of who is in the working class have also undergone major changes. Draut (2016) describes how the working class has become significantly more racially diverse since 1980, and how there has been a large increase in noncollege female labor force participation. Women make up nearly half of working class employment, an increase from previous decades (Rowell 2017), and the types of working class jobs held by men and women are very different (Hegewisch et al 2010, Draut 2016). Non-hispanic whites have decreased as a share of working class employment so that they are now under-represented in working class employment compared to the overall population, a reversal from previous decades (Rowell 2017). Indeed, Wilson (2016) projects that people of color will be the majority of the American working class by 2032. 


\section{The Precariat Class Structure}

The changing nature of the US working class described above implies the possibility of utilizing a new class scheme as a tool for understanding current trends in distribution. Wolff and Zacharias (2013) illustrate how a class structure based on Marxian concepts can be used to explain income inequality in the US. Their structure consists of capitalist, manager, supervisor, professional, white-collar skilled worker, blue-collar skilled worker, non-skilled worker, and self-employed classes. Other recent work of note has hypothesized different class systems suitable to the changing nature of work in the US. In one example, Temin (2017) postulates a class system for the modern United States based on the "dual economy" theory of Lewis (1954). He divides workers into a high skilled, highly educated, and high earning top 20\% and a lower skilled, less educated, lower earning $80 \%$ (Temin 2017). These two classes, in Temin's telling, essentially function in two completely different economies. In what could be an echo of the proficians of Standing's class hierarchy, discussed shortly, Temin also emphasizes that merely getting a college degree does not guarantee entry into the higher-earning class. Temin also emphasizes the racial component of the make-up of the two classes, with the lower class being disproportionately black and Hispanic and the upper class disproportionately white. In my opinion Temin's class system is largely compatible with Standing's more complex structure, discussed in the following paragraphs.

Standing's theory focuses on a newer, or still emerging class structure, with a particular focus on the aforementioned precariat (Standing 2009, 2014, 2015). As explained above, the precariat is largely defined by insecure employment relationships. It may include individuals such as migrants, career-less workers, temps, interns, independent contractors, and part-time workers, among others (Standing 2014).

Standing proposes six other class categories in addition to the precariat (Standing 2009, 204, 2015). These classes are the global elite, the salariat, proficians, the core working class, the unemployed and the detached. The elite is described by Standing as consisting of the top .01 percent of income earners in the US, or perhaps the wealthiest $1 \%$ of the adult population globally. They earn much of their incomes from sources other than wages or salaries. The salariat are high income earners in full time, stable employment, who tend to have salaries rather than an hourly wage. The salariat may also gain some of their income from capital, aligning their interests with the elite at times. The next class, the proficians, are skilled workers and professionals without stable, traditional employment. They might be independent contractors or consultants, for example.

The next class, the "core" or "old" working class is disproportionately male, with stable long term employment and relatively high wages. They might be part of a union, and they are more likely to have access to benefits 
through their job or the state. The precariat described above, have little job security and few benefits. They receive low pay and their jobs are more likely to be informal, casual, short term or part time, and in the service sector.

The final class categories are the long term unemployed and the detached. Standing argues that those who have been unemployed for long enough stretches should no longer be associated with their previous job, but instead be understood as a unique class with unique characteristics and interests. The final class in his system, the detached, are those suffering from chronic poverty, detached completely from work force, and may be ineligible for state benefits such as unemployment compensation.

\section{Methodology and Data}

The data used was from the US Census Bureau/Bureau of Labor Statistic (BLS)'s Current Population Survey (CPS) and the Annual Social and Economic Supplement (ASEC) for 1980, 2000, 2010, and 2018, obtained through IPUMS-CPS (Flood et al 2018). I chose to begin the study in 1980 to roughly correspond with the beginning of many of the institutional changes, and of the increase in income inequality, described above. I included 2000 and 2010 to account for cyclical effects on the trends measured, as those years are, respectively, near the top and bottom of recent business cycles. 2018 was the most recent data available. Because this study focuses on workers, I restricted the sample to those aged 18-65. For similar reasons, those who said that they did not work in the previous year because they were retired, were in school, were in the armed forces, or were taking care of family members, were also dis-included. Some further restrictions were made in the implementation of the class schema, discussed below. The variable used to measure income inequality represents each individual's total pre-tax personal income from all sources for the previous calendar year (the ASEC is conducted in March).

The unit of analysis assigned to each class and used to assess inequality is the individual worker. All of those included in one of the classes will be members of the labor force and will have worked in the past year, with the exceptions of the elites, and the unemployed/detached. I describe the class assignments in more detail in the following section. The samples are very large, several tens of thousands individuals even after the restrictions on the sample are applied. The large sample size allows for a decomposition into groups with sufficient numbers for meaningful comparisons, while also ensuring a representative national sample with a wide variety of job types and income levels present in the sample. All statistical analysis presented below was calculated with survey weights provided by IPUMS-CPS (Flood et al 2018). 


\section{Implementing the Precariat Class Schema Empirically}

In assigning individuals to each class, I aimed to keep the criteria relatively simple, while still adequately representing Standing's proposed groupings. The first step was to divide workers by the level of formal education needed for their occupations. I classified occupations using the BLS classification of occupations by "Typical education needed for entry" (BLS 2017) and the Census Bureau's 2010 occupation classification. By matching the BLS education classification with the occupations provided in the ASEC, I assigned each worker to one of two categories; in an occupation typically requiring at least a Bachelor's Degree for entry, and in an occupation typically requiring less formal education than a Bachelor's Degree for entry. ${ }^{1}$ Here I follow Draut (2016), among others, who defines the working class as individuals in the labor force who do not have bachelor's degrees.

I first placed individuals into elite class. Since Standing (2009) describes the group as the top .01\% of US income earners, any individual in the sample whose total income placed them in the top thousandth of the sample was placed in this group, regardless of the source of that income. Another trait of the elites is that a substantial portion of their income comes from sources other than wages or salaries. Therefore, I assigned additional individuals to the elite by creating a variable measuring interest, dividend, and rental income; nonlabor income. Since the variables used to create this measure were top-coded in some years, I assigned individuals to the elite class if they had total incomes placing them in the top one percent of the sample and their total non-labor income was at the level of the top code for one of the component variables. Practically, the class can be thought of as including the highest earners regardless of income source, and very high earners with substantial non-labor income

The next class, the salariat, consists of high income earners in stable, full time employment. I assigned to the salariat members of the labor force who worked last year at an occupation that typically required a college education, were not self-employed, worked full time, had no extended ( 15 or more weeks total) periods of unemployment in the previous year, and received at least some benefits (health insurance or retirement plan) through their employer.

The proficians, by contrast, are skilled workers without traditional stable employment. I assigned to the profician class members of the labor force who worked last year at an occupation that typically required a

\footnotetext{
${ }^{1}$ In a few cases for which BLS did not have a classification for typical education level, I assigned my own using the typical education level for workers in that occupation in the ASEC 2018 sample.
} 
college education at entry, but were either part-time or self-employed, or were unemployed for 15 or more weeks in the previous year, or received neither health insurance nor retirement benefits through their job.

Next, I assigned to the core working class workers who were members of the labor force, worked last year at an occupation that does not typically require a college education at entry, worked full time, were not selfemployed, did not have any extended (15 weeks or more) unemployment in the previous year, and received health insurance from their employer. These criteria were meant to capture Standing's conception of the core working class as having steady, full time work with benefits.

The precariat have little employment security, lack benefits, and work in short term, part-time, or casual jobs. I assigned to the precariat members of the labor force who worked last year at an occupation that does not typically require a college education at entry, and who either did not receive health insurance from their employer, or worked part time, or were self-employed, or were unemployed for at least 15 weeks in the previous year. These criteria were intended to capture those with unreliable, short- term, part-time, and/or benefit-free jobs.

For the final class, I've combined the final two classes in Standing's class structure, the unemployed and the detached. I've defined this class in terms similar to how the BLS (2018a) defines "discouraged workers," and those "marginally attached to the labor force." I assigned workers to this class if they didn't work last year or were not in the labor force, but gave their reason for not working in the last year as "could not find work" or "ill or disabled." I also added individuals to this class if they were not in the labor force but reported that they would like to be working. My intent with these criteria was to identify those individuals who were unwillingly disconnected from work in the last year. It should be noted that I am almost certainly underestimating the size of this group due to the limitations of my data and the restrictions I have made to my sample. For example, this method would miss those who gave a different reason for not being in the labor force (i.e. retired, taking care of family member), but would have liked to be working, or those under 18 or over 65 who may be excluded from work through no choice of their own.

[TABLE 1 ABOUT HERE]

\section{Trends Related to the Precariat Class Structure, 1980-2018}

Table 1 depicts the proportion of workers in each of these classes for 1980, 2000, 2010, and 2018. A first notable result is that the precariat makes up a substantial portion of the workers; at least a third in all four 
years, and that the overall trend over this nearly forty year period is an expansion in this class as a share of all workers. There does appear to be a cyclical element as well, as evidenced by the peak share in 2010, at the trough of a business cycle, rather than in the most recent data. Still, all three of the more recent years are three full percentage points higher than in 1980, irrespective of which portion of a business cycle that year represents. This fact suggests that there has been a secular increase in the proportion of workers in the precariat.

Perhaps even more important is the trend in the core working class. In 1980 the core working class represented a similar but significantly larger (five percentage points) proportion of workers than the precariat, at thirty-eight percent. By 2000, that position had reversed, with the working class plummeting to thirty percent of workers, now six percentage points below the share of the precariat. There also appears to be less of a cyclical element in the trend for the core working class. By 2018 the core working class represented a quarter of workers, thirteen percentage points down from 1980. A look at the components used to determine membership in either the precariat or the working class suggested that these changes were driven primarily by a substantial decline in the proportion of workers in non-college occupations that received healthcare through their employer, and secondarily by an increase in part-time workers.

The other class defined by unstable or non-traditional work, the proficians, represented a significantly smaller portion of workers, but did also increase over the period in question to nearly eight percent of workers in 2018. The salariat, perhaps surprisingly, also saw a large increase over this period, from fifteen percent to twenty percent over the thirty-eight year period. This trend may be partially driven by the sustained and substantial increase in college educated workers as a proportion of the labor force over this time period (see, for example, Brundelage 2017).

The elite is small by definition, but did grow slightly over the period. Given the way that this class has been defined, this could only mean that a higher proportion of top earners had substantial non-labor income. Finally, the unemployed/detached had both a clear cyclical element, and a secular increase, growing to nearly ten percent of the workforce in the most recent data. Recall that this proportion very likely represents an underestimate.

\section{[TABLE 2 ABOUT HERE]}




\section{Trends in Income by Class}

Table 2 shows the median income by class and by year, as well as both the percent and absolute growth of those median incomes from 1980-2018. The differences in median income are substantial, and in the expected order. Of particular interest is the drop-off in median income from the working class to the precariat, with the median of the latter group half the size of the former. The drop-off from the salariat to proficians is similarly substantial. As expected, the median income for the elites is very large, and the median income for the unemployed or detached is very low. The mean incomes of each class, displayed later in table 5, follow a similar pattern.

Also of note is how these medians changed over the period in question. Working class incomes were essentially stagnant for the period by both absolute and relative measures. Both the salariat and the precariat saw similar proportional increases in median earnings, but this resulted in a much larger absolute increase in the median income for those in the salariat. Elite incomes skyrocketed and the unemployed/detached incomes were stagnant. These patterns are even starker when observing the mean, rather than median income changes (table 5).

The net effect of the changes described in this and the previous section is a polarization. The two highest earning classes, the salariat and elite, grew, as did the lowest earning precariat and unemployed/detached. The elite also saw their incomes increase exponentially, and the salariat had substantial income gains. The core working class, in the center of these classes in terms of wages, saw their incomes stagnate and had the biggest decline in terms of share of workers. The expanding precariat did see some income increases, but they pale in comparison to the salariat or elite in absolute terms, and still leave them substantially behind even the core working class median salary of 1980. This polarization is compatible with the work of Temin (2017), discussed above, who hypothesizes the US workforce as divided into a class of highly educated high earners, and then everyone else.

\section{Changing Demographics by Class}

\section{[TABLE 3 ABOUT HERE]}

Turning next to the question of who exactly is in these classes, tables 3 and 4 illustrate the changing class breakdowns by race and gender, respectively. One interesting comparison is the differing racial patterns between the precariat and the core working class. Non-hispanic whites were underrepresented in the precariat 
class in every year, only slightly at first and then a more pronounced underrepresentation in the later years. As the precariat grew, it became less white, even relative to whites as proportion of all workers. Black workers are roughly proportionally represented in the precariat throughout. Hispanic workers are consistently overrepresented in the precariat class, and the overrepresentation becomes more pronounced over the years studied. In 2018, Hispanic workers made up nearly a quarter of the precariat, despite making up only seventeen percent of workers and only eighteen percent of the core working class. I also calculated the shares of each class by citizenship, and non-citizens were disproportionately working in the precariat for all three years $(2000,2010,2018)$ for which that data was available.

In contrast, in the core working class, Hispanic workers are only slightly overrepresented. Non-hispanic whites are roughly proportionally represented in the core working class in all four years. In 2018, while still representing a substantial portion of the core working class, non-hispanic whites are slightly underrepresented in that category. The core working class is one of two in which Black workers are consistently overrepresented; the other being the unemployed/detached class. The overrepresentation of Black workers in the unemployed/detached class is particularly substantial. In all years, non-hispanic whites are overrepresented in the elite, salariat, and profician classes.

\section{[TABLE 4 ABOUT HERE]}

Table 4 illustrates the gender proportions for each class and year. One important take-away is that the core working class is disproportionately male. The disproportionately male working class fits with Standing's (2009, 2014) description, as mentioned above. In one perhaps counter-intuitive finding, the initial male under-representation/female overrepresentation in the precariat class seems to decline over the years studied. In 2018 the gender split in the precariat class is basically proportional to workers (though that still makes the precariat substantially more female than the core working class). Another interesting result is that women are overrepresented in both the salariat and amongst proficians in 2000, 2010 and 2018.

The gender and racial breakdowns of these classes shows that these relatively simple definitions still capture the demographic trends suggested by other research, as cited above (Draut 2016, Wilson 2016, Rowell 2017). The "new," expanding working class of the precariat is less white, more Hispanic, and more female than the “old," shrinking working class. These findings, again, also comport with Temin's (2017) emphasis on the relationship between race and class in his theory. 


\section{Measuring Inequality and Decomposing Inequality by Class}

Finally, I measured inequality by year, and decomposed inequality for each year into inter-class inequality and intra-class inequality. I've used a measure of inequality known as the Krtscha Index. The Krtscha Index, an "intermediate" measurement of distribution, is the product of the coefficient of variation (a relative measure of distribution) the standard deviation (an absolute measure of distribution) (Krtscha 1994, Subramanian 2014, Subramanian 2015):

$$
\operatorname{KRTSCHA}=\left(\frac{1}{\mu} \sqrt{\sigma^{2}}\right) * \sqrt{\sigma^{2}}
$$

There are two advantages to using this measurement. First, because the Krtscha is an intermediate, or "centrist" measure of inequality, it takes into account absolute differences in income. Most commonly used measures of inequality are relative only, based on proportions of a total amount. However, some evidence suggests that people don't typically define better or worse levels of inequality in only relative terms (Harrison and Siedl 1994, Amiel and Cowell 1999, Ravallion 2014), and researchers have argued that there is not a convincing justification to use only relative measures (Amiel and Cowell 1999, Zheng 2007, Wade 2013, Subramanian 2014). Since purely absolute measurements may also be misleading (Subramanian (2014), some researchers have supported using intermediate measures which take into account both relative and absolute differences. An intermediate measure shows increased inequality when average incomes rise and the relative distribution stays the same, and decreased inequality when all incomes rise by the same absolute amount (Kolm 1976, 1976).

A second advantage of the Krtscha Index is that it is perfectly subgroup decomposable; meaning that it can be split into between group inequality and within group inequality without any overlap term or remainder (Zheng 2007, Subramanian 2015). The within group component of the Krtscha is calculated as a weighted sum of the index within in each group, and the between group component is found by calculating the index for a population in which every person's income has been replaced by the mean income of that group (Subramanian 2015). Subgroup decomposability is a very appealing trait for this study as it allows me to specify which part of the total income inequality between workers is attributable to differences between the classes as defined, and how the importance of these classes in explaining inequality has changed over time.

\section{[TABLE 5 ABOUT HERE]}

Tables 5 and 6 show the mean income and Krtscha Index by class, and the decomposition of inequality using the index, respectively. The Krtscha Index does not provide numbers that are easily interpretable to readers 
used to, for example, gini coefficients. However, it can be readily used to compare levels of inequality in different distributions. In table 5, for example, the two highest values, suggesting the highest within group inequality, are with the two "new" or emerging classes, the proficians and the precariat. This result suggests some heterogeneity in these groups. Table 5 also reports the mean income for each group, included here because the mean is an essential component for calculating the Krtscha. It is interesting to note that the mean incomes for proficians were higher than for the core working class in each year, while the median incomes were lower. Again, this finding suggest a wide distribution of incomes within the profician class.

\section{[TABLE 6 ABOUT HERE]}

Table 6 reports the decomposition of the Krtscha Index by inter-class and intra-class inequality for each year. In 1980, the decomposition assigns twenty-two percent of the total income inequality among workers to interclass inequality, a substantial enough portion to suggest that there is some explanatory power in these classes. More importantly, the share of total inequality explained by inter-class inequality is consistently rising throughout the period studied. In 2018, the inter-class inequality for this class structure explains a full 30\% of total inequality between workers. This increased explanatory power is undoubtedly linked to two previously discussed phenomena. First, the classes at both extremes of the income spectrum are growing as a share of the all workers, and the more middle income the core working class is shrinking. Second, the mean incomes of the higher earning groups, the elite and salariat, experienced substantially greater increases, in both relative terms and particularly in the absolute terms captured by the Krtscha Index. The Krtscha Index for all workers, displayed in Table 6, also shows skyrocketing overall inequality (the index is twice as large in 2018 as in 1980). So, as overall inequality increased, this class structure is explaining a growing proportion of that increasing inequality.

\section{Conclusion}

In this paper, I applied the precariat class schema developed by Standing $(2009,2014,2015)$ to data on the US workforce to illustrate an increased polarization between high earners and low earners, and between those who do and do not have quality jobs. I also used a decomposition of inequality by class to show that the precariat class structure is able to explain a substantial and growing portion of US inequality. I found that the precariat make up a large and growing share of the US work force. In contrast, the core, or "old" working class shrank precipitously during this period, and now represents a smaller relative share of the workforce. There were large differences in income between the core working class and the precariat throughout the sample. I also show that the demographics of the precariat and the old working class are substantially different 
in terms of race and gender. The precariat was less white, more Hispanic, and more female than the core working class.

The incomes of the higher earning classes, the salariat and the elite, grew substantially, particularly in absolute terms. The incomes of the core working class stagnated. The incomes of the precariat did grow, but from a very low relative base and substantially less in absolute terms compared to the high earning classes. The salariat class of highly-educated, stably employed high earners grew as a share of the workforce, as did the unemployed and detached. Combined, these trends illustrate increased polarization in the US workforce. This phenomena was also illustrated through a decomposition of inequality by class, which found that the precariat class structure explained a meaningful and growing share of US inequality. Finally, I also illustrated that insight into these difficult to measure phenomena can be gained with a simple, easily replicable class schema using plausible class definitions and publically available data.

\section{Works Cited}

Abraham, Katharine G., John C. Haltiwanger, Kristin Sandusky, and James R. Spletzer. 2018. "Measuring the Gig Economy: Current Knowledge and Open Issues." United States Census Bureau. June 8. Accessed May 29, 2019. https://www.census.gov/content/dam/Census/about/about-thebureau/adrm/FESAC/meetings/Spletzer\%20Presentation.pdf.

Acemoglu, Daron, and Pascual Restrepo. 2017. Robots and Jobs: Evidence from US Labor Market. NBER Working Paper, Cambridge, MA: National Bureau of Economic Research.

Amiel, Yoram, and Frank Cowell. 1999. Thinking About Inequality. Cambridge University Press.

Autor, David, and Anna Salomons. 2018. Is automation labor-displacing? Productivity growth, employment, and the labor share. Brookings Papers on Economic Activity, Washington, DC: Brookings Institution.

Autor, David, David Dorn, Lawrence F. Katz, Christina Patterson, and John Van Reenen. n.d. Concentrating on the Fall of the Labor Share. NBER Working Paper, Cambridge, MA: National Bureau of Economic Research.

Autor, David, Lawrence F. Katz, and Melissa S. Kearney. 2006. The Polarization of the US Labor Market. NBER Working Paper, Cambridge, MA: National Bureau of Economic Research.

Baker, Dean. 2015. The Upward Redistribution of Income: Are Rents the Story? CEPR Working Paper, Washington, DC: Center for Economic And Policy Research. 
Bloom, Nicholas. 2017. "Corporations in the Age of Inequality." Harvard Business Review. Accessed August 2017. https://hbr.org/cover-story/2017/03/corporations-in-the-age-of-inequality.

Breman, Jan, and Marcel van der Linden. 2014. "Informalizing the Economy: The Return of the Social Question at a Global Level." Development and Change 45 (5): 920-940.

Bureau of Labor Statistics (BLS). 2018. "Contingent and Alternative Employment Arrangements News Release." Bureau of Labor Statistics. June 7. Accessed May 20, 2019. https://www.bls.gov/news.release/conemp.htm.

Bureau of Labor Statistics (BLS). 2018a. "Labor Force Statistics from the Current Population Survey: Concepts and Definitions." Bureau of Labor Statistics. December 3. Accessed May 20, 2019. https://www.bls.gov/cps/definitions.htm.

Bureau of Labor Statistics (BLS). 2017. "Education and Training Data." Bureau of Labor Statistics. October 24. Accessed May 20, 2019. https://www.bls.gov/emp/documentation/education-trainingsystem.htm.

Casselman, Ben. 2018. "Maybe the Gig Economy Isn't Reshaping Work After All." The New York Times. June 7. Accessed June 15, 2018. https://mobile.nytimes.com/2018/06/07/business/economy/work-gig-economy.html.

Draut, Tamara. 2016. Sleeping Giant: How the New Working Class Will Transform America. New York: Doubleday.

Flood, Sarah, Miriam King, Renae Rodgers, Steven Ruggles, and J. Robert Warren. 2018. Integrated Public Use Microdata Series, Current Population Survey: Version 6.0 [dataset]. Minneapolis, MN: IPUMS. https://doi.org/10.18128/D030.V6.0.

Fort, Teresa C., Justin R. Pierce, and Peter K. Schott. 2018. "New Perspectives on the Decline of US Manufacturing Employment." Journal of Economic Perspectives 32 (2): 47-72.

Graham, Mark, Isis Hjorth, and Vili Lehdonvirta. 2017. "Digital labour and development: impacts of global digital labour platforms and the gig economy on worker livelihoods." European Review of Labour and Research 23 (2): 135-162.

Greenstein, Joshua. 2019 (Forthcoming). "Development Without Industrialization? Household Well-Being and Premature Deindustrialization." Journal of Economic Issues. 
Greenstein, Joshua, and Bret Anderson. 2017. "Premature Deindustrialization and the Defeminization of Labor." Journal of Economic Issues 51 (2): 446-457.

Harrison, Elizabeth, and Christian Siedl. 1994. "Perceptional Inequality and Preferential Judgements: An Empirical Examination of Distributional Axioms." Public Choice 79: 61-81.

Hegewisch, Ariane, Hannah Liepman, Jeffrey Hayes, and Heidi Hartmann. 2010. Separate and Not Equal? Gender Segregation in the Labor Market and the Gender Wage Gap. Research Briefing Paper, Washington, DC: Institute for Women's Policy.

Hill, Steven. 2015. Raw Deal: How the 'Uber Economy' and Runaway Capitalism Are Screwing American Workers. New York: St. Martin's Press.

Howell, David R., and Arne L. Kalleberg. 2019. Declining Job Quality in the United States: Explanations and Evidence. Washington, DC: Washington Center for Equitable Growth.

International Labor Organization (ILO). 2015. Work Employment and Social Outlook: The Changing Nature of Jobs. Geneva: International Labor Organization.

Kaplan, Steven N., and Joshua Rau. 2013. "It's the Market: The Broad-Based Rise in the Return to Top Talent." Journal of Economic Perspectives 27 (3): 35-56.

Katz, Lawrence F., and Alan B. Krueger. 2016. The Rise and Nature of Alternative Work Arrangements in the United States, 1995-2015. NBER Working Paper, Cambridge, MA: National Bureau of Economic Research.

Katz, Lawrence F., and Alan Krueger. 2019. Understanding Trends in Alternative Work Arrangements in the United States. NBER Working Paper, Washington, DC: National Bureau of Economic Research.

Kolm, Serge-Christophe. 1976. "Unequal Inequalities I." Journal of Economic Theory 12: 416-442.

Kolm, Serge-Christophe. 1976. "Unequal Inequalities II." Journal of Economic Theory 13: 82-111.

Krtscha, Manfred. 1994. "A New Compromise Measure of Inequality." In Models and Measurement of Welfare Inequality, by Wolfgang Eichhorn, 111-120. Heidelberg: Springer-Verlag.

Kunst, David. 2019. Premature Deindustrialization through The Lens of Occupations: Which Jobs, Why, and Where? Amsterdam: Tinbergen Institute and Vrije Universiteit Amsterdam, School of Business and Economics. 
Lewis, W. Arthur. 1954. "Economic Development with Unlimited Supplies of Labor." (The Manchester School).

Maye, Adewale. 2019. "We're Not All Going to Be Gig Economy Workers After All." Center for Economic Policy and Research. February 28. Accessed May 5, 2019. http://cepr.net/blogs/cepr-blog/we-re-notall-going-to-be-gig-economy-workers-after-all.

McMillan, Margaret, and Dani Rodrik. 2012. Globalization, Structural Change, and Productivity Growth. IFPRI Discussion Paper 01160, Washington, DC: International Food Policy Research Institute (IFPRI).

Naidu, Suresh. 2017. "A Political Economy Take on W/Y." In After Piketty, by Heather Boushey, J. Bradford DeLong and Marshall Steinbaum, 99-125. Cambridge, MA: Harvard University Press.

Piketty, Thomas. 2013. Capital in the Twenty-First Century. Harvard University Press.

Piketty, Thomas, Emmanuel Saez, and Gabriel Zucman. 2016. Distributional National Accounts: Methods and Estimates for the United States. NBER Working Paper Series.

Ravallion, Martin. 2014. "Income Inequality in the Developing World." Science 344 (6186): 851-55.

Rowell, Alex. 2017. "What Everyone Should Know About America's Diverse Working Class." Center for American Progress. December 11. Accessed February 2018. https://www.americanprogressaction.org/issues/economy/reports/2017/12/11/169303/everyoneknow-americas-diverse-working-class/.

Shambaugh, Jay, Ryan Nunn, and Lauren Bauer. 2018. "Independent workers and the modern labor market." Brookings Institute. June 7. Accessed August 16, 2018. https://www.brookings.edu/blog/up-front/2018/06/07/independent-workers-and-the-modernlabor-market/.

Standing, Guy. 2009. Work After Globalization: Building Occupational Citizenship. Northhampton, MA: Edwin Elgar.

Standing, Guy. 2014. The Precariat. New York: Bloomsbury.

Standing, Guy. 2015. "The Precariat and Class Struggle." RCCS Annual Review (7): 3-16.

Stiglitz, Joseph E. 2013. The Price of Inequality. New York: W.W. Norton. 
Subramanian, S. 2015. "Assessing Inequality in the Presence of Growth: An Expository Essay." The Review of Black Political Economy (Madras Institute of Development Studies) 42 (3): 179-199.

Subramanian, S. 2014. "Dividing a Cake: How its Size Matters When We Make Judgments on Inequality." Journal of Philosophical Economics 7 (2): 2-19.

Tcherneva, Pavlina R. 2015. "When a rising tide sinks most boats: trends in US income inequality." Real World Econmics Review (71): 64-74.

Temin, Peter. 2017. The Vanishing Middle Class: Prejudice and Power in a Dual Economy. Cambridge, MA: The MIT Press.

United Nations Research Institute for Social Development(UNRISD). 2010. Combating Poverty and Inequality: Structural Change, Social Policy and Politics. Geneva: UNRISD.

US Government Accountability Office (GAO). 2015. Contingent Workforce: Size, Characteristics, Earnings, and Benefits. Washington, DC: US Government Accountability Office.

van der Hoeven, Rolph. 2012. Development Aid and Employment. Working Paper No. 2012/107, Helsinki, Finland: UNU World Institute for Development Economics Research (UNU-WIDER).

Vernon Brundage, Jr. 2017. "Profile Of The Labor Force By Educational Attainment." Bureau of Labor Statistics. August 2017. Accessed May 28, 2019. https://www.bls.gov/spotlight/2017/educationalattainment-of-the-labor-force/home.htm.

Wade, Robert H. 2013. "Our Misleading Measure of Income and Wealth Inequality: the Standard Gini Coefficient." Triple Crisis. May 6. Accessed February 8, 2017. http://triplecrisis.com/our-misleadingmeasure-of-income-and-wealth-inequality-the-standard-gini-coefficient/.

Wakabayashi, Daisuke. 2019. "Google’s Shadow Work Force: Temps Who Outnumber Full-Time Employees." The New York Times. May 28. Accessed May 28, 2019. https://www.nytimes.com/2019/05/28/technology/google-tempworkers.html?action=click\& module=Top Stories\& pgtype=Homepage.

Weil, David. 2014. The Fissured Workplace. Cambridge, MA: Harvard University Press.

Wilson, Valerie. 2016. People of Color Will be a Majority of the American Working Class in 2032. Washington, DC: Economic Policy Institute. 
Wolff, Edward N., and Ajit Zacharias. 2013. "Class structure and economic inequality." Cambridge Journal of Economics 37: 1381-1406.

Zheng, Buhong. 2007. "Unit-Consistent Decomposable Inequality Measures." Economica 74 (293): 97-11. 


\begin{tabular}{|l|r|r|r|r|}
\hline \multicolumn{5}{|c|}{ Table 1. Workers in Each Class by Year (\%) } \\
\hline Class & 1980 & 2000 & 2010 & 2018 \\
\hline Elite & 0.08 & 0.10 & 0.10 & 0.17 \\
\hline Salariat & 15.52 & 19.42 & 18.34 & 20.96 \\
\hline Profician & 5.76 & 6.13 & 6.51 & 7.57 \\
\hline $\begin{array}{l}\text { Core } \\
\text { Working } \\
\text { Class }\end{array}$ & 38.98 & 30.72 & 25.01 & 25.71 \\
\hline Precariat & 33.03 & 36.22 & 37.97 & 36.01 \\
\hline $\begin{array}{l}\text { Unemployed/ } \\
\text { Detached }\end{array}$ & 6.63 & 7.40 & 12.07 & 9.58 \\
\hline All & 100 & 100 & 100 & 100 \\
\hline Source: Author's calculations using Flood et al (2018). \\
\hline
\end{tabular}

\begin{tabular}{|c|c|c|c|c|c|c|}
\hline Class & 1980 & 2000 & 2010 & 2018 & $\begin{array}{l}\% \\
\text { Change } \\
1980- \\
2018 \\
\end{array}$ & $\begin{array}{l}\text { Abs. } \\
\text { Change } \\
1980- \\
2018 \\
\end{array}$ \\
\hline Elite & 272,439 & 437,393 & 561,588 & $1,098,699$ & $303.3 \%$ & 826,260 \\
\hline Salariat & 62,455 & 70,696 & 73,159 & 75,013 & $20.1 \%$ & 12,558 \\
\hline Profician & 31,022 & 36,668 & 40,004 & 41,984 & $35.3 \%$ & 10,962 \\
\hline $\begin{array}{l}\text { Core Working } \\
\text { Class }\end{array}$ & 43,955 & 44,145 & 45,719 & 44,347 & $0.9 \%$ & 392 \\
\hline Precariat & 20,262 & 22,240 & 22,859 & 24,970 & $23.2 \%$ & 4,708 \\
\hline $\begin{array}{l}\text { Unemployed/ } \\
\text { Detached }\end{array}$ & 8,700 & 9,388 & 9,144 & 8,809 & $1.3 \%$ & 110 \\
\hline All & 35,447 & 36,931 & 34,289 & 37,955 & $7.1 \%$ & 2,507 \\
\hline
\end{tabular}




\begin{tabular}{|c|c|c|c|c|c|c|}
\hline \multicolumn{7}{|c|}{ Table 3. Racial Composition of Classes by Year (\%) } \\
\hline & \multicolumn{3}{|c|}{1980} & \multicolumn{3}{|c|}{2000} \\
\hline & $\begin{array}{l}\text { White } \\
\text { (non- } \\
\text { hispanic) }\end{array}$ & $\begin{array}{l}\text { Black } \\
\text { (non- } \\
\text { hispanic) }\end{array}$ & Hispanic & $\begin{array}{l}\text { White } \\
\text { (non- } \\
\text { hispanic) }\end{array}$ & $\begin{array}{l}\text { Black } \\
\text { (non- } \\
\text { hispanic) }\end{array}$ & Hispanic \\
\hline Elite & 97.22 & 0.00 & 2.78 & 77.28 & 0.00 & 17.25 \\
\hline Salariat & 90.13 & 5.37 & 2.55 & 81.33 & 8.76 & 4.25 \\
\hline Profician & 90.35 & 4.75 & 3.07 & 82.04 & 6.69 & 6.10 \\
\hline "Old" Working Class & 81.50 & 11.08 & 5.68 & 72.76 & 13.30 & 10.27 \\
\hline Precariat & 81.45 & 10.52 & 6.13 & 68.12 & 11.93 & 15.41 \\
\hline Unemployed/Detached & 68.47 & 24.02 & 5.65 & 60.49 & 22.87 & 12.17 \\
\hline \multirow[t]{2}{*}{ All } & 82.48 & 10.49 & 5.19 & 72.41 & 12.21 & 10.86 \\
\hline & \multicolumn{3}{|c|}{2010} & \multicolumn{3}{|c|}{2018} \\
\hline Elite & 67.89 & 9.49 & 16.35 & 75.34 & 3.83 & 4.71 \\
\hline Salariat & 76.26 & 8.20 & 6.36 & 70.98 & 9.17 & 8.43 \\
\hline Profician & 75.32 & 7.41 & 8.79 & 70.83 & 8.69 & 10.72 \\
\hline Core Working Class & 67.33 & 12.76 & 13.89 & 60.10 & 14.16 & 18.71 \\
\hline Precariat & 61.45 & 10.90 & 20.80 & 56.11 & 12.22 & 23.79 \\
\hline Unemployed/Detached & 56.66 & 21.27 & 15.74 & 54.85 & 22.45 & 15.55 \\
\hline All & 65.97 & 11.89 & 15.03 & 61.28 & 12.78 & 17.45 \\
\hline
\end{tabular}




\begin{tabular}{|l|r|r|r|r|}
\hline \multicolumn{5}{|c|}{ Table 4. Gender Composition of Classes by Year (\%) } \\
\hline & \multicolumn{2}{|c|}{1980} & \multicolumn{2}{c|}{2000} \\
\hline Elite & Male & \multicolumn{1}{c|}{ Female } & Male & Female \\
\hline Salariat & 82.71 & 17.29 & 82.52 & 17.48 \\
\hline Profician & 63.74 & 36.26 & 51.34 & 48.66 \\
\hline "Old" Working Class & 50.70 & 49.30 & 41.32 & 58.68 \\
\hline Precariat & 64.51 & 35.49 & 60.60 & 39.40 \\
\hline Unemployed/Detached & 49.94 & 50.06 & 49.99 & 50.01 \\
\hline All & 48.55 & 51.45 & 51.20 & 48.80 \\
\hline & 57.74 & 42.26 & 53.10 & 46.90 \\
\hline Elite & \multicolumn{2}{|c|}{2010} & \multicolumn{2}{|c|}{2018} \\
\hline Salariat & 56.64 & 43.36 & 75.30 & 24.70 \\
\hline Profician & 49.67 & 50.33 & 49.52 & 50.48 \\
\hline Core Working Class & 44.62 & 55.38 & 42.58 & 57.42 \\
\hline Precariat & 57.71 & 42.29 & 60.15 & 39.85 \\
\hline Unemployed/Detached & 52.34 & 47.66 & 52.08 & 47.92 \\
\hline All & 53.25 & 46.75 & 51.39 & 48.61 \\
\hline Source: Author's calculations using Flood et al (2018). & \multicolumn{4}{|c|}{} \\
\hline
\end{tabular}




\begin{tabular}{|c|c|c|c|c|}
\hline \multicolumn{5}{|c|}{$\begin{array}{l}\text { Table 5. Mean Income and Krtscha Index } \\
\text { Group (2017 Dollars) }\end{array}$} \\
\hline & \multicolumn{2}{|c|}{1980} & \multicolumn{2}{|c|}{2000} \\
\hline Class & Mean & $\begin{array}{l}\text { Krtscha } \\
\text { Index }\end{array}$ & Mean & $\begin{array}{l}\text { Krstcha } \\
\text { Index }\end{array}$ \\
\hline Elite & 278,190 & 13914 & 457,314 & 10461 \\
\hline Salariat & 70,483 & 19551 & 86,801 & 41307 \\
\hline Profician & 44,652 & 44625 & 53,031 & 65650 \\
\hline $\begin{array}{l}\text { "Old" } \\
\text { Working } \\
\text { Class } \\
\end{array}$ & 48,785 & 12998 & 51,942 & 22104 \\
\hline Precariat & 29,567 & 38525 & 34,083 & 60342 \\
\hline \multirow[t]{2}{*}{$\begin{array}{l}\text { Unemployed/ } \\
\text { Detached }\end{array}$} & 11,963 & 18309 & 13,297 & 27866 \\
\hline & \multicolumn{2}{|c|}{2010} & \multicolumn{2}{|c|}{2018} \\
\hline Elite & 558,019 & 6367 & 792,364 & 144703 \\
\hline Salariat & 92,675 & 62684 & 94,236 & 63111 \\
\hline Profician & 55,068 & 76166 & 60,490 & 82023 \\
\hline $\begin{array}{l}\text { Core Working } \\
\text { Class }\end{array}$ & 53,282 & 30811 & 55,823 & 53940 \\
\hline Precariat & 34,080 & 67152 & 37,270 & 78505 \\
\hline $\begin{array}{l}\text { Unemployed/ } \\
\text { Detached }\end{array}$ & 11,740 & 26625 & 12,192 & 41435 \\
\hline
\end{tabular}




\begin{tabular}{|c|c|c|c|c|c|c|c|c|}
\hline \multicolumn{9}{|c|}{ Table 6. Decomposed Krtscha Index of Income Inequality by Year (2017 dollars) } \\
\hline & \multicolumn{2}{|c|}{1980} & \multicolumn{2}{|c|}{2000} & \multicolumn{2}{|c|}{2010} & \multicolumn{2}{|c|}{2018} \\
\hline & $\begin{array}{l}\text { Index } \\
\text { Value }\end{array}$ & $\begin{array}{l}\text { Share } \\
(\%)\end{array}$ & $\begin{array}{l}\text { Index } \\
\text { Value }\end{array}$ & $\begin{array}{l}\text { Share } \\
(\%)\end{array}$ & $\begin{array}{l}\text { Index } \\
\text { Value }\end{array}$ & $\begin{array}{l}\text { Share } \\
(\%)\end{array}$ & $\begin{array}{l}\text { Index } \\
\text { Value }\end{array}$ & $\begin{array}{l}\text { Share } \\
(\%)\end{array}$ \\
\hline $\begin{array}{l}\text { Inter-Class } \\
\text { Inequality }\end{array}$ & 6893 & 22 & 12626 & 23 & 17670 & 25 & 27879 & 30 \\
\hline $\begin{array}{l}\text { Intra-Class } \\
\text { Inequality }\end{array}$ & 24621 & 78 & 42766 & 77 & 52880 & 75 & 65786 & 70 \\
\hline $\begin{array}{l}\text { Total } \\
\text { Inequality }\end{array}$ & 31514 & 100 & 55393 & 100 & 70550 & 100 & 93665 & 100 \\
\hline
\end{tabular}

